\title{
Stage dependent variability in tractive force distribution through a riffle-pool sequence
}

\author{
D.J. Milan ${ }^{\mathrm{a}, *}$, G.L. Heritage ${ }^{\mathrm{b}}$, A.R.G. Large ${ }^{\mathrm{a}}$, M.E. Charlton ${ }^{\mathrm{a}}$ \\ ${ }^{a}$ Department of Geography, University of Newcastle upon Tyne, Daysh Building, Claremont Road, \\ Newcastle upon Tyne NE1 TRU, UK \\ ${ }^{\mathrm{b}}$ Department of Geography, University of Salford, Salford M5 4WP, UK
}

Received 28 January 2000; received in revised form 15 August 2000; accepted 13 September 2000

\begin{abstract}
High resolution data on spatial and temporal variability in flow hydraulics and sediment transport within riffle-pool sequences are required to improve understanding of how fluvial processes maintain these meso-scale bedforms. This paper addresses this issue by providing velocity and boundary shear stress data over a range of discharges from base flow $\left(0.07 \mathrm{~m}^{3} \mathrm{~s}^{-1}\right)$ to just over bankfull $\left(8.52 \mathrm{~m}^{3} \mathrm{~s}^{-1}\right)$, from a sequence of four pools and three riffles in the River Rede, Northumberland. The data supports the reversal hypothesis of Keller [Geol. Soc. Am. Bull. 87 (1971) 753.] as the primary explanation for the maintenance of the riffle-pool sequence, although they also indicate that spatial variability in tractive force is highly stage dependent and complex. Section-averaged velocity data indicate reversal to be evident at four out of six riffle-pool units. An equalisation in velocity was found for the other two riffle-pool units close to bankfull stage. The spatial patterns of tractive force exhibited in the study reach as a result of increased discharge demonstrate that riffle-pool units operate independently of one another. Shear stress reversals were observed in individual riffle-pool units at different river stages during a flood hydrograph, and in some instances, two occurred in the same riffle-pool unit during a single flow event. Pools were characterised by coarser bed sediments and narrower channel widths in comparison to riffles, increasing the likelihood of tractive force reversal in the River Rede. Areas of predicted bed sediment entrainment obtained from $\tau_{\mathrm{o}}-\tau_{\mathrm{c}}$, matched observed channel changes in the upper part of the study reach, but over-estimated change in the middle portion of the reach. (C) 2001 Elsevier Science B.V. All rights reserved.
\end{abstract}

Keywords: Tractive force; Boundary shear stress; Gravel-bed river; Velocity reversal hypothesis; Riffle-pool; Sediment transport

\footnotetext{
* Corresponding author. Tel.: +44-191-222-8510; fax: +44-191-222-5421.

E-mail address: d.j.milan@ncl.ac.uk (D.J. Milan).
} 


\section{Introduction}

Riffles and pools are common meso-scale bedform features in gravel-bed rivers with moderate slopes (less than 5\%), and may be defined respectively as positive and negative residuals of a regression line fitted to the longitudinal bed profile (Richards, 1976a). The non-uniform bed topography characteristic of riffle-pool sequences has been shown to be important in maintaining quasi-equilibrium in the fluvial system (Leopold et al., 1964; Dolling, 1968; Keller and Melhorn, 1978), by minimising the potential energy loss per unit mass of water (Yang, 1971) or minimising total power expenditure (Cherkauer, 1973). Riffles and pools also constitute a valuable habitat resource for aquatic ecosystems (Greenwood and Richardot-Coulet, 1996; Milan et al., in press), and it is now recognised that river engineering and rehabilitation projects should be based on a thorough understanding of the fluvial processes responsible for their formation and maintenance (Brookes, 1990, 1992; Newbury, 1995). Such an understanding requires knowledge of spatial and temporal variability in flow hydraulics and sediment transport within riffle-pool sequences under a range of flows up to, and exceeding, bankfull discharge (Keller, 1982).

\subsection{Riffle-pool maintenance}

The riffle-pool unit occupies a central place in the study of gravel-bed rivers, where attention has been focused towards their formation, functioning and maintenance (see for example reviews by Carling, 1991; Clifford and Richards, 1992; Sear, 1992a, 1996). The primary aspect of this research has concerned hydraulic and sediment transport processes where the velocity reversal hypothesis has emerged as a principal area of debate (Table 1). While Gilbert (1914) was the first to observe velocity reversal, Keller (1971) was the first to place both observations and quantitative data in a theoretical framework. Keller (1971) used near-bed velocity as a surrogate for tractive force or stream power, and was able to demonstrate an equalisation in velocity between pools and riffles at high stage. From a limited set of data, Keller hypothesised that velocity reversal was responsible for the maintenance of highs and lows in the bed longitudinal profile, and the areal sorting mechanisms operating within these bedforms (hence, why riffles become coarser than pools). A reversal in tractive force is dependent upon the interaction of water discharge with channel morphology, slope and bed roughness. Below the reversal threshold, when the tractive force of the riffle is greater than the pool, sand and fine gravel (phase 1 bedload) is transported over a stable coarse surface layer (Jackson and Beschta, 1982). If sufficient material is available, fines will be winnowed into the downstream pool where they will settle onto the bed surface and into the intragravel voids (Lisle and Hilton, 1992, 1999). As discharge rises, two things happen: (a) the tractive force of the pools increase at a faster rate, and eventually exceed that of the riffles, and (b) the riffle armour layer is mobilised, signalling the initiation of phase 2 transport (medium and coarse gravel). Once mobilised, gravel is routed downstream where it is deposited on riffles where either the tractive force is lower than the critical threshold for entrainment or the rate of inflowing bed material exceeds the transport capacity of the riffle. Gravel bedload tends not to settle in pools due to the 
greater tractive force. On the falling limb of the hydrograph, the coarse material is stranded on the riffles and fines are winnowed into the pools. Consequently, the largest clasts are usually reported on riffles and relatively finer material in pools.

A review of the literature presented in Table 1 located seven studies to support the reversal hypothesis with actual measurements (Andrews, 1979; Lisle, 1979; Teissyre, 1984; Ashworth, 1987; Petit, 1987; Sear, 1996; Thompson et al., 1999). Further studies were found to accept the hypothesis although they were unable to provide field evidence to support it, but a number of other papers strongly disagree with the hypothesis. Indeed, several workers including Gilbert (1914) and Bhowmik and Demissie (1982a) contend that if pools have a higher maximum tractive force, then the coarser material should occur in the pools. A small number of other workers (e.g. Hack, 1957; Lisle, 1979) have also reported a coarse immobile lag which is exposed through scour of sand at high flow and then covered again by sand on the falling limb of the hydrograph. Hence, the observed low flow grain-size character of pools and riffles are a product of the entire range of discharges.

Comparison of the results of different studies in Table 1 is complicated by the varied sampling strategies and methodologies employed. Problems arise particularly because: (a) data sets often cover only a restricted range of discharge conditions; (b) there is often poor consistency between reach sizes and the number of riffles and pools (most studies look either at single riffle-pool units or riffle-pool units which are widely spaced); and (c) a range of hydraulic measurements have been used to characterise the flow. More recent studies (e.g. Sear, 1996) use boundary shear stress in place of velocity to represent the tractive force. Most of these studies estimate local boundary shear stresses from velocity profiles by assuming a semi-logarithmic relationship between depth and velocity, commonly referred to as the 'law of the wall'. This procedure requires a large number of velocity measurements close to the bed, and in practice, problems may be encountered due to: (a) zero-plane displacement errors (particularly on shallow riffles) related to the point where the base of the current meter rests on the bed (Ferguson, 1993); (b) the effects of large roughness elements (e.g. Clifford and Richards, 1992), where the use of velocity profiling has been shown to be limited to depth to grain size $\left(D_{84}\right)$ ratios < ca. 3 (Bray, 1980); (c) instrument errors; (d) an insufficient number of velocity readings; (e) the use of a single current meter instead of a sampling array; and (f) insufficient measuring time to account for variability due to turbulent velocity fluctuations and burst-sweep effects (see, for example, Heslop and Allen, 1989).

It is clear from the review of past studies (Table 1) that the spatial resolution of measurements has been poor and that the range of flows investigated has been limited. As a result, further data on flow hydraulics, sediment transport and areal sorting mechanisms are required to improve understanding of the fluvial processes responsible for maintaining riffle-pool sequences. Specifically, there is a need for (i) a data set that extends through sequences of pool-riffle units, (ii) one which includes both straight and curved reaches, (iii) one that features high-intensity hydraulic measurements by providing point rather than cross-section averaged measurements, and for (iv) the data set to cover a wide range of stages up to and including bankfull. The field study reported here addresses these needs firstly by testing the velocity reversal hypothesis on the River Rede riffle-pool sequence by using cross-section averaged velocity measurements for 
Table 1

Selected studies on riffle-pool hydraulics and sediment transport

\begin{tabular}{llll}
\hline River and source & Site details & Hydraulic measurement \\
\hline $\begin{array}{l}\text { Dry Creek, California, Keller (1970, } \\
\text { 1971, 1972) }\end{array}$ & $\begin{array}{l}\text { Single pool-riffle unit, } 75 \mathrm{~m} \text { in } \\
\text { length }\end{array}$ & Mean near-bed velocity
\end{tabular}
length

Teleki (1972)

River Fowey, Cornwall, Richards (1976a,b, 1978)

East Fork River, Wyoming, Lisle (1979)

Flynn Creek, Oregon Coastal Range, Jackson and Beschta (1982)

Kaskasia River, Illinois, Bhowmik and Demissie (1982a,b)

River Bôbr, Poland, Teissyre (1984)

Boulder Creek, Utah, O’Connor et al. (1986)
Four sections; two adjacent rifflepool units, one straight the other sinuous, in three reaches

Two riffle-pool sections, $1 \mathrm{~km}$ apart

Mean boundary shear stress, calculated using Du Boys formula

Sequence of two riffles and two pools, $45 \mathrm{~m}$ long reach, 3-4 m wide. Discharge ranged from 0.8 to 1.53 $\mathrm{m}^{3} \mathrm{~s}^{-1}$

One straight $366 \mathrm{~m}$, one sinuous 305 $\mathrm{m}$ riffle-pool reach, both reaches contained two riffles and one pool Three observations $0.6 \mathrm{~km}$ reach, 10 riffle-pool units Point velocity 0.6 depth. Average velocity in the vertical

Velocity, water surface slope, Froude number

Mean section velocity. Assumed semi-log profile

Stream power, HEC 2-Simulation
Observations

Velocity equalisation

Highlighted the importance of the boundar layer and suggested Keller's results shoul be re-examined

As discharge increased, pool-riffle mea velocities showed some convergence bu did not equalise

Pool water surface gradient steepened with an increase in discharge; shear stress reversal occurred. Lisle later re-evaluated these results to demonstrate equalisation

Peak velocity in the pools moved closer the bed as discharge rose

Riffle velocities always higher for thre different discharges. Rejected reversal hy pothesis

Velocity and shear stress reversal

Stream power and water slope reversa Bedrock channel, no bed adjustment poss ble 
River La Rulles, Ardennes, Petit (1987)

Alt Dubaig, River Feshie, Scotland, Ashworth (1987)

East Fork River, Wyoming, Andrews (1979)

River, Quarme, UK, Clifford and Richards (1992)

River Severn, Shropshire, Carling (1991)

River Severn, Shropshire, Carling and Wood (1994)
Meandering section, approximately eight pool-riffle units, $100 \mathrm{~m}$ reach

Six different channel patterns including straight, meandering and braided. Alt Dubaig; seven reaches each comprised a single riffle-pool unit. Measurements made between 0.4-10 $\mathrm{m}^{3} \mathrm{~s}^{-1}$. Bankfull $=10 \mathrm{~m}^{3} \mathrm{~s}^{-1}$. Fes hie; two riffle pool sub-units, between 11 and $23 \mathrm{~m}^{3} \mathrm{~s}^{-1}$. Bankfull $=25 \mathrm{~m}^{3} \mathrm{~s}^{-1}$

Water surface slope measured on 17 occasions over full range of flows Bankfull $=250 \mathrm{~m}^{3} \mathrm{~s}^{-1}$

Single riffle pool unit $30 \mathrm{~m}$ in length, straight reach. Seven flows analysed

Two 1-km sinuous reaches, both with two riffles and pools

Two 1-km sinuous reaches, both with two riffles and pools-used for model validation
Direct velocity measurement and calculation of shear stress from Du Boys formula. Assumed semi-log profile

Shear stress from velocity profiles (four measuring heads) and from Du Boys formula. Assumed semi-log profile

\section{Mean section velocity}

Velocity profiles obtained by direct measurement along a series of cross-profiles. Assumed semi-log profile

Section-average shear velocity. Six point measurements spaced over the lower $0.5 \mathrm{~m}$ of the wading rod. Velocity profiles with a $r^{2}>95 \%$ were used.

HEC-2 simulation, assumed straight prismatic channel
Shear stress reversal

Found shear stress reversal in five reache out of seven near or just below bankfull

Reversal in mean velocity below bankfu for one riffle-pool pair. No contiguou riffle-pool sections showed reversal

Velocity convergence was found, no reve sal was identified

Equalisation of mean flow parameters oc curred at high flow

Rivers with hydraulically rougher pools comparison to adjacent riffles were mor likely to show a competence reversal. Th critical discharge at which reversal occurre was a negative function of riffle spacin and riffle width relative to pool width 
Table 1 (continued)

\begin{tabular}{llll}
\hline River and source & Site details $\quad$ Hydraulic measurement
\end{tabular}

River North Tyne, Northumberland, Three straight reaches between 3 Velocity profiles five to seven points Sear (1992a,b,c, 1996) and $6 \mathrm{~km}$ apart comprised two pools and a riffle. Reach lengths from 150 to $500 \mathrm{~m}$ in the bottom $20 \%$ flow depth. As-

Sediment transport reversal. Concluded tha velocity reversal was not required to explai sumed semi-log profile. Flows $>45$ $\mathrm{m}^{3} \mathrm{~s}^{-1}$, shear stress derived from Du Boys equation, calculated using cross-sectional averaged velocity.

Assumed uniform flow

Dry Creek, California, Keller and Singlepool-riffle unit $75 \mathrm{~m}$ in length HEC-2 simulation scour, fill and sedimentology of riffle-poo sequences

Florsheim (1993)

River Quarme, UK, Robert (1997)

$100 \mathrm{~m}$ straight reach, two pools, two riffles, width $=8-10 \mathrm{~m}, D_{50}=36$ $\mathrm{mm}$

Thompson et al. (1999)

Field and flume study. Single riffle-pool-riffle unit $50 \mathrm{~m}$ in

length. Coarser pools than riffles. Five flows, including one just over

Velocity profiling over three flows up to two-thirds bankfull

Water surface elevations

Velocityreversal occurred at high flows

Equalisation attwo-thirds bankfull bankfull

Reversal in water surface slope. Maxim located in pool in the vicinity of a boulde obstruction. Equalisation in slope when con sidering average values along thalweg 
21 flows. Tractive force variability over the discharge range is then examined more closely by using boundary shear stress data for five flows, including one at bankfull, to elucidate the complexity of riffle-pool hydraulics. The use of boundary shear stress permits a close examination of sediment transport potential and morphological change.

\section{Study reach}

The field study was performed on the River Rede, which is a 58-km long tributary of the River Tyne, rising at $490 \mathrm{~m}$ A.O.D. in the Cheviot Hills in Northumberland, UK (Fig. 1a). The selected reach is about $4.5 \mathrm{~km}$ from the source (National Grid Reference; NT 721 043), where the river has a Strahler (1952) stream order of four and comprises a single-thread, cobble-bed channel with four pools and three riffles along the 175-m-long study reach. The Rede drains a catchment of about $18 \mathrm{~km}^{2}$ in area, with an impermeable geology of Carboniferous sandstones and shales overlain by peat and boulder clay. The mean annual runoff is $1026 \mathrm{~mm}$ and the flow regime is flashy, with flood peaks being reached in less than $2 \mathrm{~h}$. Bankfull discharge is approximately $8.5 \mathrm{~m}^{3} \mathrm{~s}^{-1}$. Surface grain size data draped over bed surface morphology is shown in Fig. 2. The data, obtained from 41 quadrats situated throughout the study reach using the Wolman (1954) grid-by-number technique, indicate that pools are coarser and thus physically rougher $\left(D_{50}=122 \mathrm{~mm}\right)$ than the riffles $\left(D_{50}=101 \mathrm{~mm}\right)$.

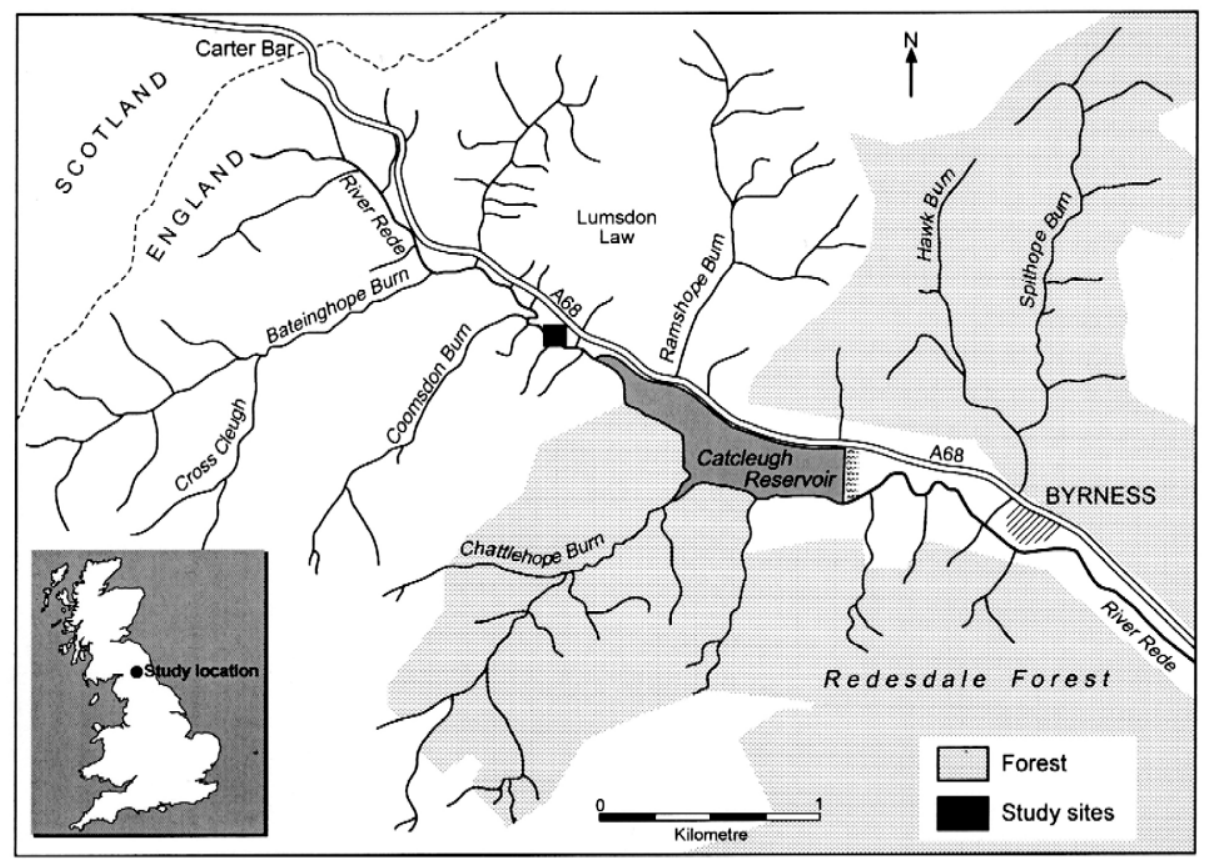

Fig. 1. The River Rede, Northumberland, site location. 


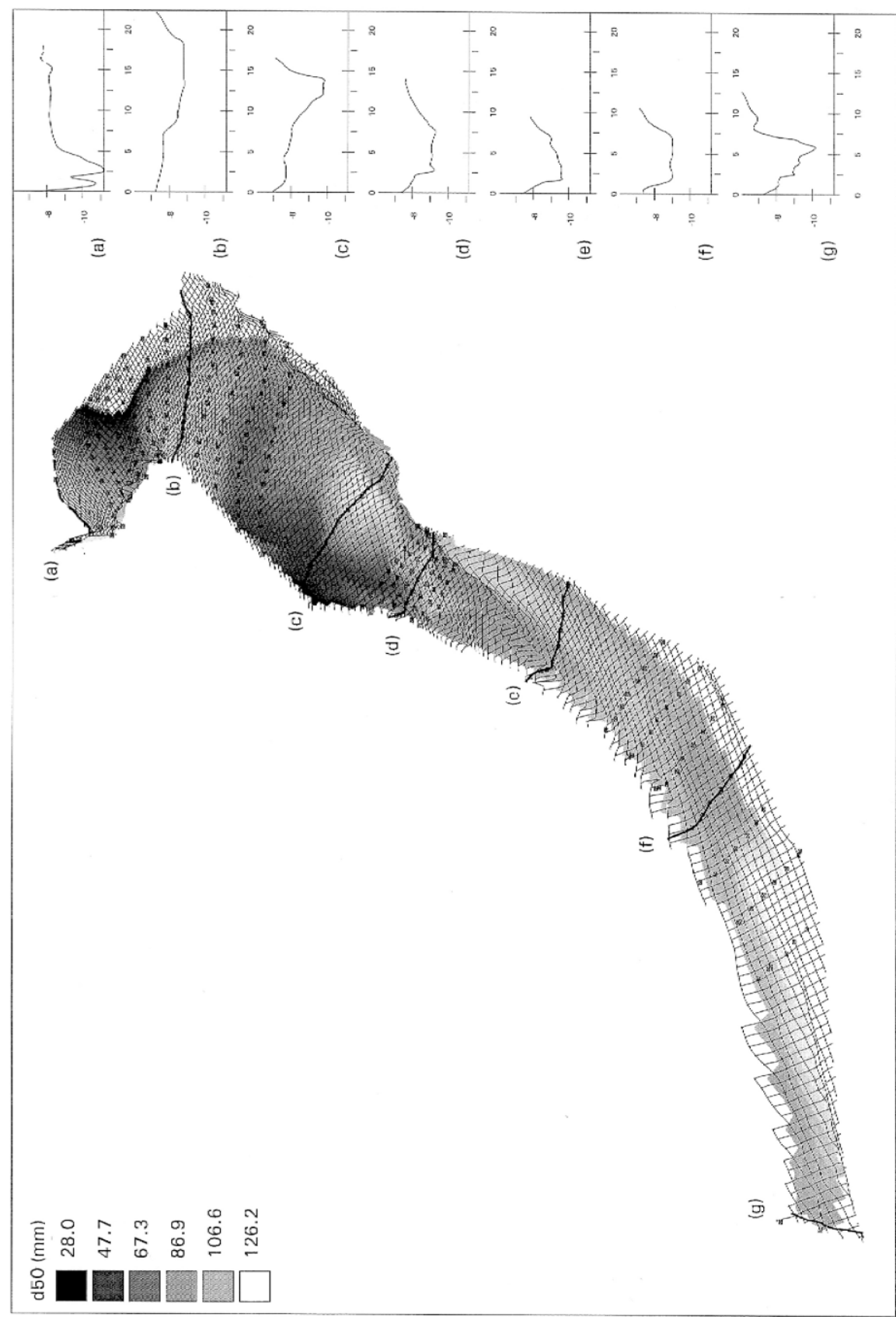




\section{Methods and techniques}

\subsection{Morphology}

The longitudinal profile of the study reach was surveyed at the inception of the project and 30 cross-sections were established to determine initial cross-section areas, wetted perimeters and cross-stream depth distributions (Fig. 2). The survey was repeated 1 year later, in conjunction with visual observations made during and after flood events during the intervening period, to identify net morphological change. A selection of cross-sections from the second survey demonstrate channel morphology throughout the reach (Fig. 2).

\subsection{Determination of velocity}

Cross-section averaged velocity was estimated from stage data obtained at seven cross-sections situated at the crest of the riffles and in the troughs of the pools. Continuous discharge was measured at a permanent gauging station situated $50 \mathrm{~m}$ upstream of the riffle-pool sequence under study. Velocities were obtained by dividing the discharge peaks for 21 flood hydrographs by the wetted area derived from each of the cross-sections.

\subsection{Determination of critical boundary shear stress for entrainment}

The critical boundary shear stress, $\tau_{\mathrm{c}}$, required to mobilise bed material was estimated by rearranging the Shields equation, to yield:

$$
\tau_{\mathrm{c}}=\theta_{\mathrm{c}}\left(\rho_{\mathrm{s}}-\rho_{\mathrm{w}}\right) g D_{50}
$$

where $\theta_{\mathrm{c}}$ is the critical dimensionless shear stress, $\rho_{\mathrm{s}}$ is the density of sediment (2650 $\left.\mathrm{kg} \mathrm{m}{ }^{-3}\right), \rho_{\mathrm{w}}$ is the water density $\left(1000 \mathrm{~kg} \mathrm{~m}^{-3}\right), \mathrm{g}$ is the acceleration due to gravity (9.81 $\mathrm{m} \mathrm{s}^{-2}$ ) and $D_{50}$ is the 50th percentile fraction of surface bed material sediments. The values customarily assumed for $\theta_{c}$ are 0.06 for well-sorted sediments and 0.047 for poorly sorted sediments (Miller et al., 1977), although Buffington and Montgomery (1997) have highlighted that values may range from 0.052 to 0.086 for reference-based studies and $0.030-0.073$ for visually based studies. A range of factors including non-uniform grain size distribution and particle shape have been suggested to account for this range. Andrews (1983), who worked on a naturally formed gravel-bed channel,

Fig. 2. Perspective plot indicating spatial variability of median grain size for surface sediments draped over channel morphology. Cross-sectional survey positions are indicated as is the morphology of seven representative cross-sections (a-g). Grain-size data was obtained from a cell-based Wolman (1954) grid survey. The plot is viewed looking upstream at an azimuth of $210^{\circ}$ from north, an altitude of $30^{\circ}$, and a distance of $119 \mathrm{~m}$ (from centre). Mesh size is $1 \mathrm{~m}$. Cross-section units are in metres. 
found that for particles between 0.3 and 4.2 times the $D_{50}$ of the subsurface bed material, the average $\theta_{c}$ was equal to

$$
\theta_{\mathrm{c}}=0.0834\left(D_{i} / D_{50}\right)^{-0.872}
$$

where $D_{i}$ is the diameter of the $i$ th percentile fraction of the surface bed material and the $D_{50}$ is the diameter of the 50th percentile fraction of the sub-surface bed material. $\theta_{c}$ for the Rede was therefore calculated using this approach, which utilised surface sediment data, and subsurface sediment data obtained using a freeze-core technique (see Milan et al., 1999). The average value of $\theta_{c}$, which is employed herein was 0.052 and ranged from 0.034 to 0.13 .

Eq. (1) was used to derive a measure of entrainment potential by subtracting the critical boundary shear stress $\left(\tau_{\mathrm{c}}\right)$ for the $D_{50}$ from local bed shear stress values $\left(\tau_{\mathrm{o}}\right)$ calculated using hydraulic data. The amount by which $\tau_{\mathrm{o}}$ exceeds $\tau_{\mathrm{c}}$ indicates the sediment transport potential. It is important to note that this measure of competence does not necessarily indicate areas of scour and fill, as it does not take into account sediment flux. This flux is likely to be an important factor in streams with a high sediment supply, where transport capacity is high and the competence threshold low (Lisle, personal communication, 1998). This argument will not apply under the supply-limited conditions encountered in most UK gravel-bed rivers, including the River Rede.

\subsection{Determination of bed shear stresses}

Water surface profiles were surveyed on five occasions (Fig. 3), using a combination of water surface and trash-line measurements, for stages ranging from summer base flow $\left(0.07 \mathrm{~m}^{3} \mathrm{~s}^{-1}\right)$ to approximately bankfull discharge $\left(8.52 \mathrm{~m}^{3} \mathrm{~s}^{-1}\right)$. For each stage, the

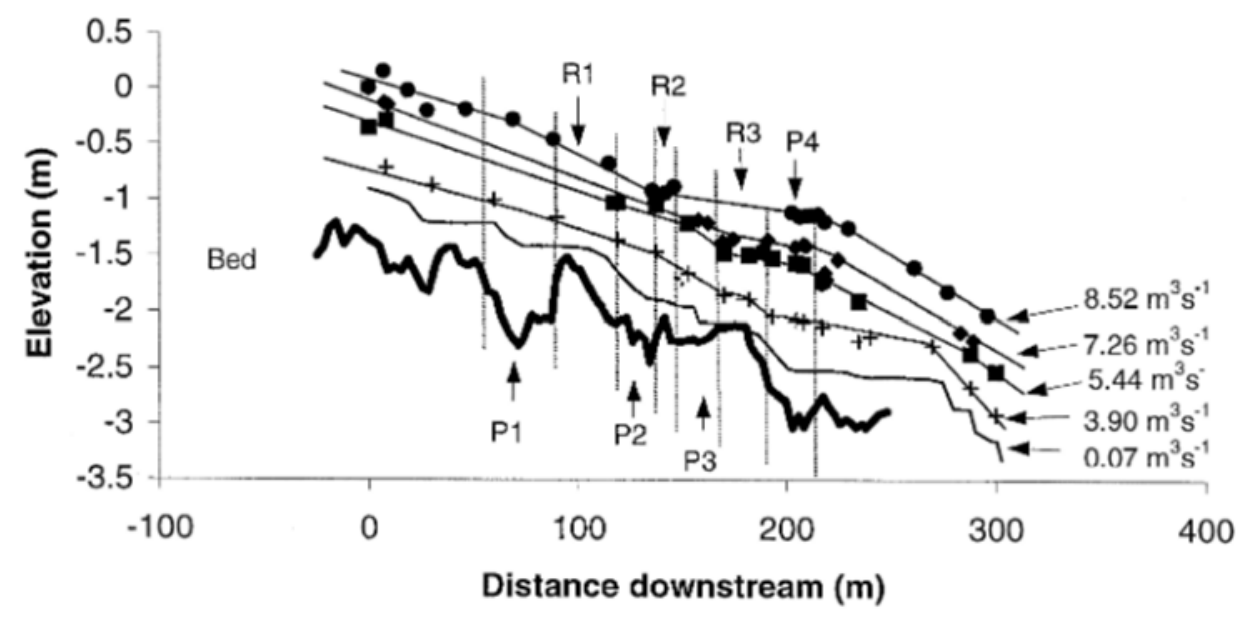

Fig. 3. Long profile of bed and water surface slopes $\left(0.07-8.5 \mathrm{~m}^{3} \mathrm{~s}^{-1}\right)$ relative to an arbitrary datum, illustrating the equalisation of water surface slopes and the drowning-out of riffle-pool morphology effects, resulting in steady flow conditions at higher discharges. The riffles and pools indicated occupy the sub-reaches between the vertical dividing lines. 
local water surface slope was calculated for each riffle and pool, which typically ranged between $0.03 \%$ and $2 \%$. Cross-stream depth distributions were recorded at each of the 30 cross-sections by subtracting water surface from bed surface elevation. As it was impossible to observe the bed at the higher stages, the coarseness of the bed material introduces some imprecision in the measurement of bed elevations. The thickness of the line indicating the bed in Fig. 3 has been scaled to represent the likely error margin.

Riffle-pool morphology introduces flow convergence and divergence, acceleration and deceleration, the magnitude of which is related to the degree of change in cross-sectional wetted area with distance downstream between sections. Bathurst (1977) demonstrated this by considering 'profile' shear velocity $\bar{U}^{*}$, which may by obtained from the varied-flow equation:

$$
\bar{U}_{*}^{2}=g R S+\frac{\bar{U}^{2}}{P} \frac{d_{\mathrm{A}}}{d_{\mathrm{x}}}
$$

where $R$ is hydraulic radius, $S$ is the energy slope, $\bar{U}^{2}$ is the average velocity, $P$ is the wetted perimeter, $d_{\mathrm{A}}$ is the change in area between successive cross-sections, and $d_{\mathrm{x}}$ is the distance between the same cross-sections. In non-uniform flow propulsive and resistive forces are not in balance and the shear velocity $\bar{U}^{z}$ must be related to the rate of change of momentum (Bathurst, 1977):

$$
\bar{U}_{*}^{2}-g R S=\frac{\bar{U}^{2}}{P} \frac{d_{\mathrm{A}}}{d_{\mathrm{x}}}
$$

The degree of non-uniformity is indicated by the ratio of propulsive and resistive forces $\beta$ obtained from Eq. (4) (Bathurst, 1977):

$$
\beta=\frac{g R S}{\bar{U}_{*}^{2}}
$$

In uniform flow $\beta$ is unity and in accelerating and decelerating flow it is respectively greater and less than unity. In order to establish the maximum degree of expansion and contraction, $\beta$ coefficients were evaluated for a sequence of cross-sections taken at the crest of each riffle and the trough of each pool throughout the study reach. The data are plotted in Fig. 4, where it may be seen that deviation from unity is generally less than \pm 0.1 . Strongest non-uniform effects are not found at the lowest flow, as may be expected, but at a slightly higher discharge of $2 \mathrm{~m}^{3} \mathrm{~s}^{-1}$. At this flow, strong accelerative effects were shown between pool 2 (P2) and riffle 2 (R2) and P3-R3 where there were deviations from unity of +0.19 and +0.49 , respectively. Less strong decelerative effects were shown between R2-P3 where there was a deviation of -0.2 from unity. The only other notable deviation is shown at a discharge of $7.26 \mathrm{~m}^{3} \mathrm{~s}^{-1}$ between P2-R2 where flow deceleration results in a $\beta$ value of -0.31 . With the exception of data obtained at $2 \mathrm{~m}^{3} \mathrm{~s}^{-1}$ and that obtained between P2 and R2 at $7.26 \mathrm{~ms}^{-1}$, it appears reasonable to approximate the flow as being uniform. This assumption is further substantiated by the work of Bhowmik (1982a,b), which indicates that uniform flow 


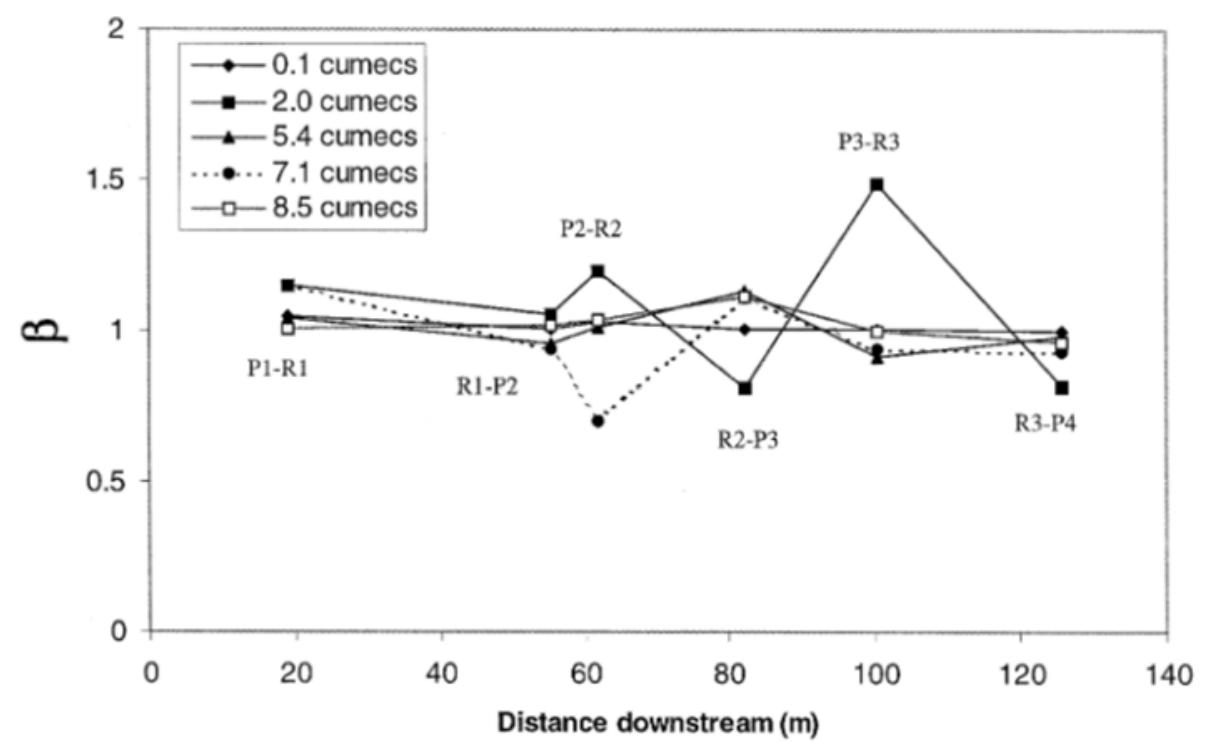

Fig. 4. Downstream variation of the $\beta$ coefficient, indicating the magnitude of acceleration $(+v e)$ and deceleration ( - ve) effects for five different discharges from baseflow to bankfull. Non-uniform effects appear to be most pronounced at $2 \mathrm{~m}^{3} \mathrm{~s}^{-1}$, whereas deviation from unity for all other flows is generally \pm 0.1 indicating negligible accelerative and decelerative effects.

may be assumed for medium to high discharges, largely due to the flattening out of the water surface slope at higher discharges and the drowning-out of riffle-pool morphology, which may be seen from the water surface profiles shown in Fig. 3.

The survey data were entered into the Du Boys equation to calculate local bed shear stresses $\left(\tau_{0}\right)$, assuming that the flow was approximately uniform and that the energy slope could be approximated by the local water surface slope:

$$
\tau_{\mathrm{o}}=\rho_{\mathrm{w}} g d S
$$

where $d$ is the flow depth.

Another factor, which may influence shear stress estimates in pools situated on bends, are the influences of transverse water surface slopes due to super-elevation of curved flow (e.g. Whiting and Dietrich, 1991). This was considered using:

$$
Z=\frac{U^{2} W}{g r^{2}}
$$

where $Z$ is super-elevation, $W$ is water width, and $r$ is bend radius. Super-elevations were calculated for the five flows studied in detail and were found to be negligible, being only of the order of $1 \mathrm{~mm}$ or less, and therefore insufficient to affect bed shear stresses. 


\section{Results}

\subsection{Velocity reversal hypothesis}

Fig. 5 demonstrates cross-section averaged velocity data for six riffle-pool units throughout the study reach. Marginal velocity reversals are evident for four out of the six riffle-pool units: P2-R2, R2-P3, P3-R3, R3-P4 (Fig. 5c-f). In the middle of the reach, reversal in velocity occurs when flows exceed around one-third bankfull at 2-3 $\mathrm{m}^{3} \mathrm{~s}^{-1}$ (Fig. 5c and d), whereas further down the reach a reversal occurs at bankfull discharge at 7-9 $\mathrm{m}^{3} \mathrm{~s}^{-1}$ (Fig. 5e and f). A reversal is not evident at the upstream-most part of the reach between $\mathrm{P} 1-\mathrm{R} 1$ and $\mathrm{R} 1-\mathrm{P} 2$, however there is a velocity equalisation at around bankfull. Log-log regressions presented in Fig. 5 consistently indicate steeper slope exponents for the pool data. This suggests, in comparison to riffles, that pool velocities increase at a faster rate as discharge rises. Although the velocity data provide useful information, limitations are encountered due to its cross-section averaged nature. For example, close to bankfull there appears to be a slight reduction in the rate at which velocity increases as discharge progressively rises, which may possibly reflect over-spill onto bar surfaces or the floodplain. Furthermore, the increase in wetted cross-sectional area as bar surfaces are drowned may prevent cross-section average velocity reversal occurring at some pool-riffle units (e.g. P1-R1), even though the central core of velocity within the pool trough may exceed that of the adjacent riffles. The boundary shear stress data overcomes these drawbacks to an extent by providing a finer resolution, taking into account some 530 points through the study reach, as well as allowing an assessment of sediment transport potential.

\subsection{Boundary shear stress distribution}

Table 2 provides a summary of the spatial and temporal pattern of riffle-pool hydraulics, grain roughness, channel wetted width and sediment transport potential. More detailed information on point boundary shear stress are presented using grey-scale plots (Fig. 6a-d), ranging from the lowest to the highest flow $\left(0.07\right.$ and $8.52 \mathrm{~m}^{3} \mathrm{~s}^{-1}$, respectively).

At low flow, the highest shear stress zones are situated on the head of R1 on the left-hand bank, on the head of P2 and the tail of R3/head of P4 (Table 2). P1 and P3 have very gentle water surface slopes and experience very low shear stresses (cf. Fig. 3). Conversely, the steepest slope recorded at low flow is found on R1. Notably, the mean boundary shear stresses in P2 and P4 were greater than on the adjacent riffles. This is not consistent with the results of previous studies and might result from errors in shear stress calculations for low flows (Bathurst, 1982).

At $5.44 \mathrm{~m}^{3} \mathrm{~s}^{-1}$ high shear stresses are particularly evident in the middle and downstream portions of the reach, where mean values of 120 and $101 \mathrm{~N} \mathrm{~m}^{-2}$ were found in P2 and P4, respectively (Fig. 6b). The boundary shear stress in the trough of P1 exceeds that of the downstream riffle (R1). It should be noted that high pool shear stresses are only located in the deeper part of the pool, areas of the bar which begin to be submerged at this stage actually have lower shear stress in comparison to the riffle 

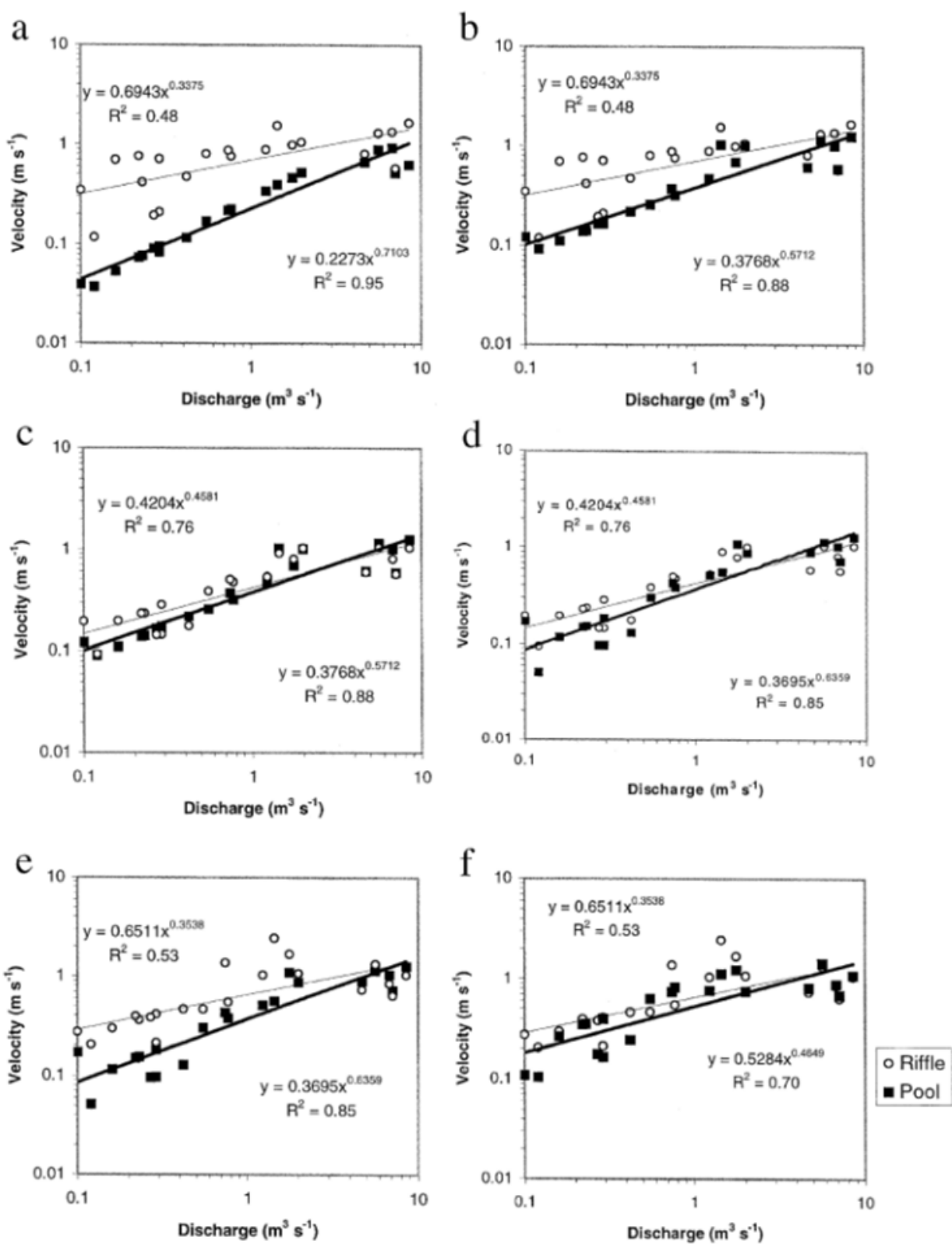

Fig. 5. Cross-section averaged velocity pattern with increasing discharge for six riffle-pool units throughout the study reach, (a) Pool 1 and Riffle 1; (b) Riffle 1 and Pool 2; (c) Pool 2 and Riffle 2; (d) Riffle 2 and Pool 3; (e) Pool 3 and Riffle 3; (f) Riffle 3 and Pool 4. Black squares represent pool data, open circles represent riffle data. Velocity reversal is evident for four out of six riffle-pool units. Log-log regressions $(p<0.001)$ indicate greater slope exponents for pools, demonstrating a greater rate of increase in velocity in comparison to the riffles for a given rise in discharge. 
Table 2

Summary of changes in boundary shear stress with increasing discharge and factors which influence riffle-pool hydraulics

\begin{tabular}{|c|c|c|c|c|c|c|c|c|c|c|c|c|c|}
\hline & P1 & $\mathrm{P} 1-\mathrm{R} 1$ & R1 & R1-P2 & P2 & P2-R2 & R2 & R2-P3 & P3 & P3-R3 & R3 & R3-P4 & P4 \\
\hline $\begin{array}{l}\text { Slope } \\
\text { range }\end{array}$ & $0.0003-0.0094$ & $\begin{array}{l}\text { Reversal } \\
\text { at } 7.26 \\
\mathrm{~m}^{3} \mathrm{~s}^{-1}\end{array}$ & $0.0028-0.0184$ & $\begin{array}{l}\text { Reversall } \\
\text { at } 3.9 \\
\text { and } 8.52 \\
\mathrm{~m}^{3} \mathrm{~s}^{-1}\end{array}$ & $0.0028-0.0184$ & $\begin{array}{l}\text { Pool shows } \\
\text { greater slope } \\
\text { at low flow }\end{array}$ & $0.0022-0.0203$ & $\begin{array}{l}\text { Reversal } \\
\text { at } 7.26 \\
\mathrm{~m}^{3} \mathrm{~s}^{-1}\end{array}$ & $0.0021-0.0123$ & $\begin{array}{l}\text { Pool has } \\
\text { greater } \\
\text { slope at } \\
\text { low flow }\end{array}$ & $0.0023-0.0128$ & $\begin{array}{l}\text { Two } \\
\text { reversals } \\
\text { at } 5.44 \\
\text { and } 8.52 \\
\mathrm{~m}^{3} \mathrm{~s}^{-1}\end{array}$ & $0.0045-0.0124$ \\
\hline $\begin{array}{l}\text { Channel } \\
\text { wetted } \\
\text { width } \\
\text { range (m) }\end{array}$ & $3.5-18.4$ & & $6.7-19.0$ & & $3.0-15.0$ & & $5.0-14.7$ & & $3.5-9.3$ & & $6.0-11.9$ & & $3.0-10.0$ \\
\hline $\begin{array}{l}\text { Shear } \\
\text { stress } \\
\text { range } \\
\left(\mathrm{Nm}^{-2}\right)\end{array}$ & $0.03-176.9$ & $\begin{array}{l}\text { Reversal } \\
\text { at } 5.44 \\
\mathrm{~m}^{3} \mathrm{~s}^{-1}\end{array}$ & $1.9-94.18$ & $\begin{array}{l}\text { Reversal } \\
\text { at } 5.44 \\
\text { and } 8.52 \\
\mathrm{~m}^{3} \mathrm{~s}^{-1}\end{array}$ & $4.96-116.32$ & $\begin{array}{l}\text { Reversal } \\
\text { at } 7.26 \\
\mathrm{~m}^{3} \mathrm{~s}^{-1}\end{array}$ & $0.06-207.39$ & $\begin{array}{l}\text { Reversal } \\
\text { at } 3.9 \\
\text { and } 8.52 \\
\mathrm{~m}^{3} \mathrm{~s}^{-1}\end{array}$ & $7.98-123.14$ & $\begin{array}{l}\text { Reversal } \\
\text { at } 3.9 \\
\text { and } 8.52 \\
\mathrm{~m}^{3} \mathrm{~s}^{-1}\end{array}$ & $0.7-72.49$ & $\begin{array}{l}\text { Reversal } \\
\text { at } 5.44 \\
\mathrm{~m}^{3} \mathrm{~s}^{-1}\end{array}$ & $0.05-350.35$ \\
\hline $\begin{array}{l}\text { Grain } \\
\text { roughness } \\
(\mathrm{mm})\end{array}$ & $\begin{array}{l}D_{84}=193 \\
D_{50}=120 \\
D_{16}=83\end{array}$ & & $\begin{array}{l}D_{84}=132 \\
D_{50}=79 \\
D_{16}=43\end{array}$ & & $\begin{array}{l}D_{84}=190 \\
D_{50}=120 \\
D_{16}=73\end{array}$ & & $\begin{array}{l}D_{84}=152 \\
D_{50}=85 \\
D_{16}=45\end{array}$ & & $\begin{array}{l}D_{84}=164 \\
D_{50}=112 \\
D_{16}=86\end{array}$ & & $\begin{array}{l}D_{84}=173 \\
D_{50}=101 \\
D_{16}=66\end{array}$ & & $\begin{array}{l}D_{84}=120 \\
D_{50}=82 \\
D_{16}=42\end{array}$ \\
\hline $\begin{array}{l}\text { Entrainment } \\
\text { potential } \\
\left(\mathrm{m}^{3} \mathrm{~s}^{-1}\right)\end{array}$ & $Q>5.44$ & $Q>7.27$ & $Q>7.27$ & $Q>7.27$ & $Q>3.90$ & $Q>3.90$ & $Q>5.44$ & $Q>5.44$ & $Q>7.26$ & $Q>7.26$ & $Q>8.52$ & $Q>5.44$ & $Q>5.44$ \\
\hline
\end{tabular}




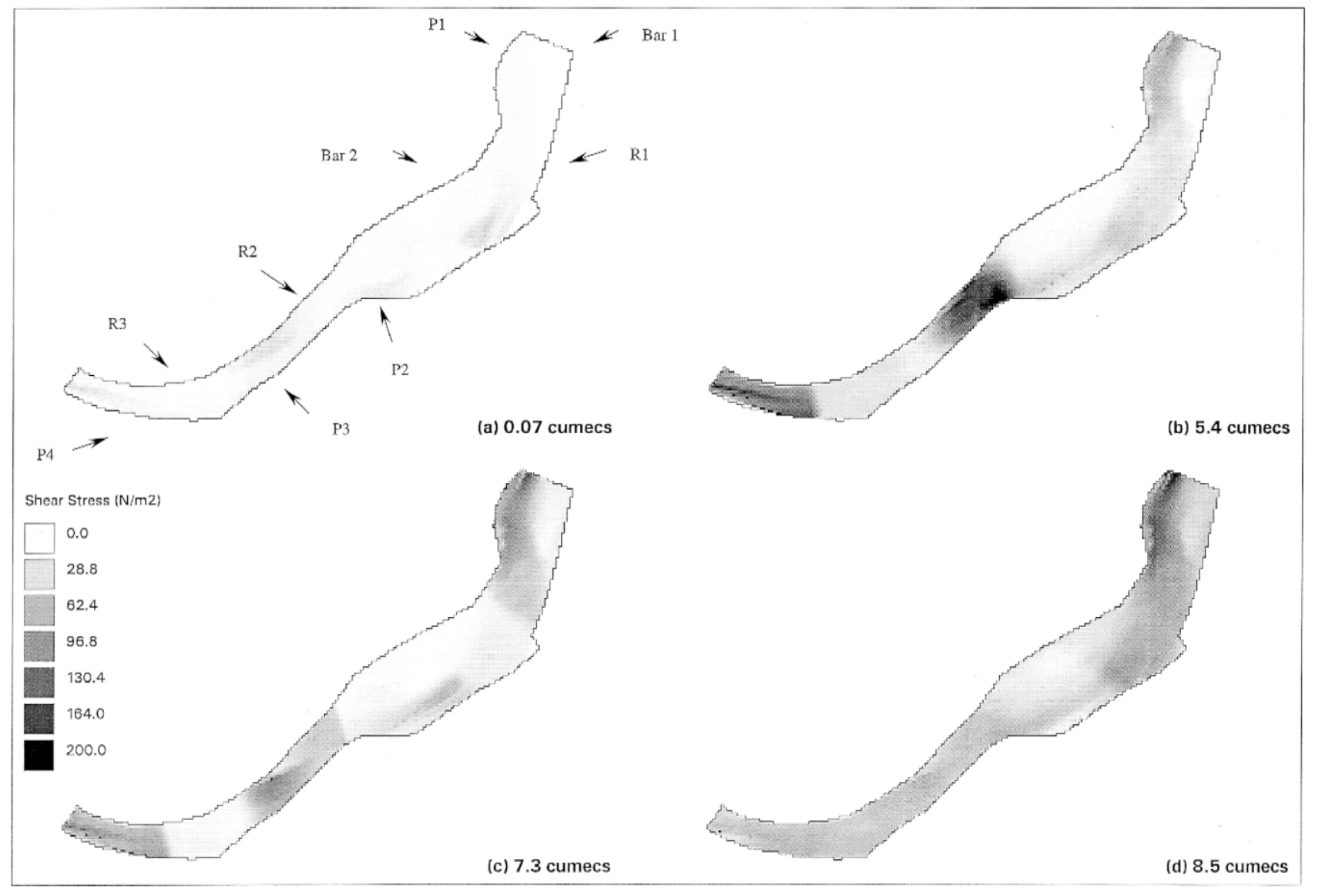

Fig. 6. Grey-scale plots indicating spatial patterns of point boundary shear stress derived using the Du Boys equation, for (a) $0.07 \mathrm{~m}^{3} \mathrm{~s}^{-1}$, (b) $5.44 \mathrm{~m}^{3} \mathrm{~s}^{-1}$, (c) 7.26 $\mathrm{m}^{3} \mathrm{~s}^{-1}$, (d) $8.52 \mathrm{~m}^{3} \mathrm{~s}^{-1}$. 
downstream. At this same discharge R1 and R2 all show slight shear stress increases, while R2 and R3 still display higher shear stresses than P3. The reversal noted in the velocity data between P2-R2 is also evident in the boundary shear stress data at this flow. Boundary shear stress peaks are now located at the head and centre of P2, and throughout R3 and P4.

At $7.26 \mathrm{~m}^{3} \mathrm{~s}^{-1}$, just below bankfull flow, boundary shear stress in P1 reaches its maximum with the tail of P1 showing a slight increase in shear stress. However, the head of R1 shows a reduction in shear stress and downstream of P1 there is a general decline in stresses compared to those under the previous discharge of $5.44 \mathrm{~m}^{3} \mathrm{~s}^{-1}$ (see Fig. 6b and c). Shear stress reversals are in evidence between P1-R1, R2-P3 and P3-R3 where pool shear stress exceeds riffle (cf. Table 2). Mean boundary shear stresses in P1 and P4 remain higher than those on R1 and R3, respectively. Other notable changes are that the high shear stress zone on the crest of R1 near the left-hand bank re-emerges, the region of high shear found in P2 at the previous flow shows a slight reduction, and the peak stress is found further downstream towards the tail of P2 and the head of R2. The tail of R2 and P3 show low shear stresses whereas R3 and P4 both show a further increase.

At bankfull discharge $\left(8.52 \mathrm{~m}^{3} \mathrm{~s}^{-1}\right)$, there is little difference in water surface slope between morphological units, however, pool slopes do tend to marginally exceed riffle slopes (Table 2). A maximum boundary shear stress of $225 \mathrm{~N} \mathrm{~m}^{-2}$ is found in P4 at this flow. The surface of bar 1 is fully drowned, and an increase in boundary shear stress may be observed on the shallow water over the bar surface (Fig. 6d). Most of the pool-riffle units, with the exception of R3-P4, show a trend towards equalisation; however, the pool shear stresses still generally exceed those on the riffles (e.g. P1-R1, R2-P3, P3-R3, R3-P4). Overall, the boundary shear stress data support the interpretation of velocity data for bankfull, with the exception of P1-R1 and R1-P2.

\subsection{Predicted areas of potential morphological change}

Positive values for $\tau_{\mathrm{o}}-\tau_{\mathrm{c}}$ were plotted to indicate areas of potential entrainment and channel change for four discharges (Fig. 7a to d). At bankfull discharge (8.52 $\mathrm{m}^{3} \mathrm{~s}^{-1}$ ), there is potential for entrainment of the $D_{50}$ in P1, and the head of R1 in the channel centre. No scour is predicted for bar 2 or the middle/tail of R1, therefore deposition is likely to occur in these zones at this stage. Localised regions of entrainment are predicted in P2, the tail of R2 and along the right bank of P3. No scour is found at the head of R3, therefore deposition is likely in this area. Scour is however predicted along the left bank and tail of R3 and P4. At just below bankfull $\left(7.26 \mathrm{~m}^{3} \mathrm{~s}^{-1}\right), \mathrm{P} 1$ still appears competent to entrain the $D_{50}$. Entrainment is more localised however, and deposition is likely to occur between the tail of P1 and the head of R1. Some localised entrainment is also predicted on P3, however as R3 is incapable of transporting any material, sediments scoured from P3 would be deposited here. Some potential entrainment is also predicted in at the tail of R3 and P4.

At $5.44 \mathrm{~m}^{3} \mathrm{~s}^{-1}$ there is limited entrainment in P1, again suggesting that some deposition might occur just downstream of this point. The most extensive area of sediment motion is found to occur at this flow (two-thirds bankfull) in P2 and head of 


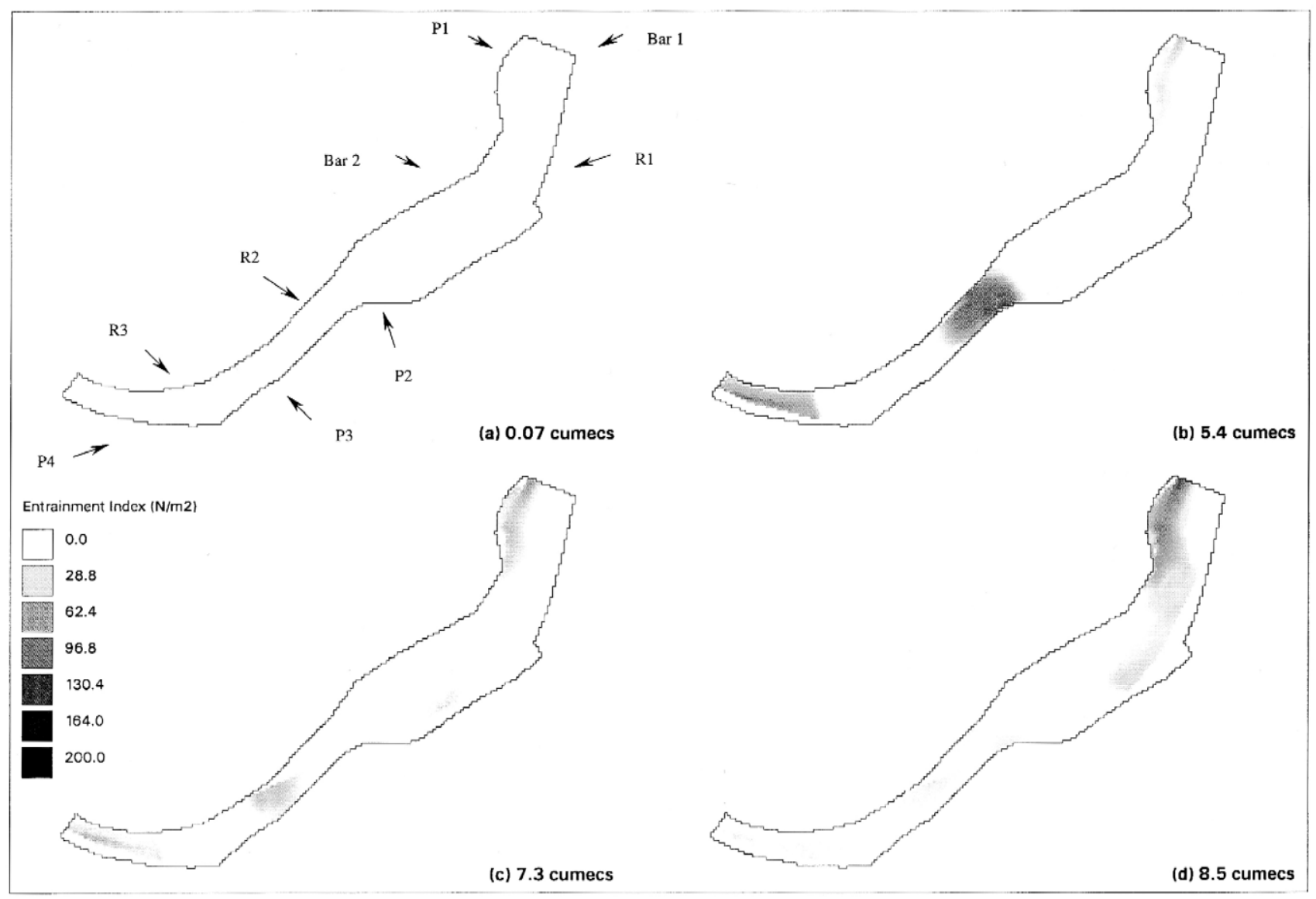

Fig. 7. Grey-scale plots indicating predicted spatial pattern of scour $\left(\tau_{\mathrm{o}}-\tau_{\mathrm{c}}\right)$ at (a) $0.07 \mathrm{~m}^{3} \mathrm{~s}^{-1}$, (b) $5.44 \mathrm{~m}^{3} \mathrm{~s}^{-1}$, (c) $7.26 \mathrm{~m}^{3} \mathrm{~s}^{-1}$, (d) $8.52 \mathrm{~m}^{3} \mathrm{~s}^{-1}$. 


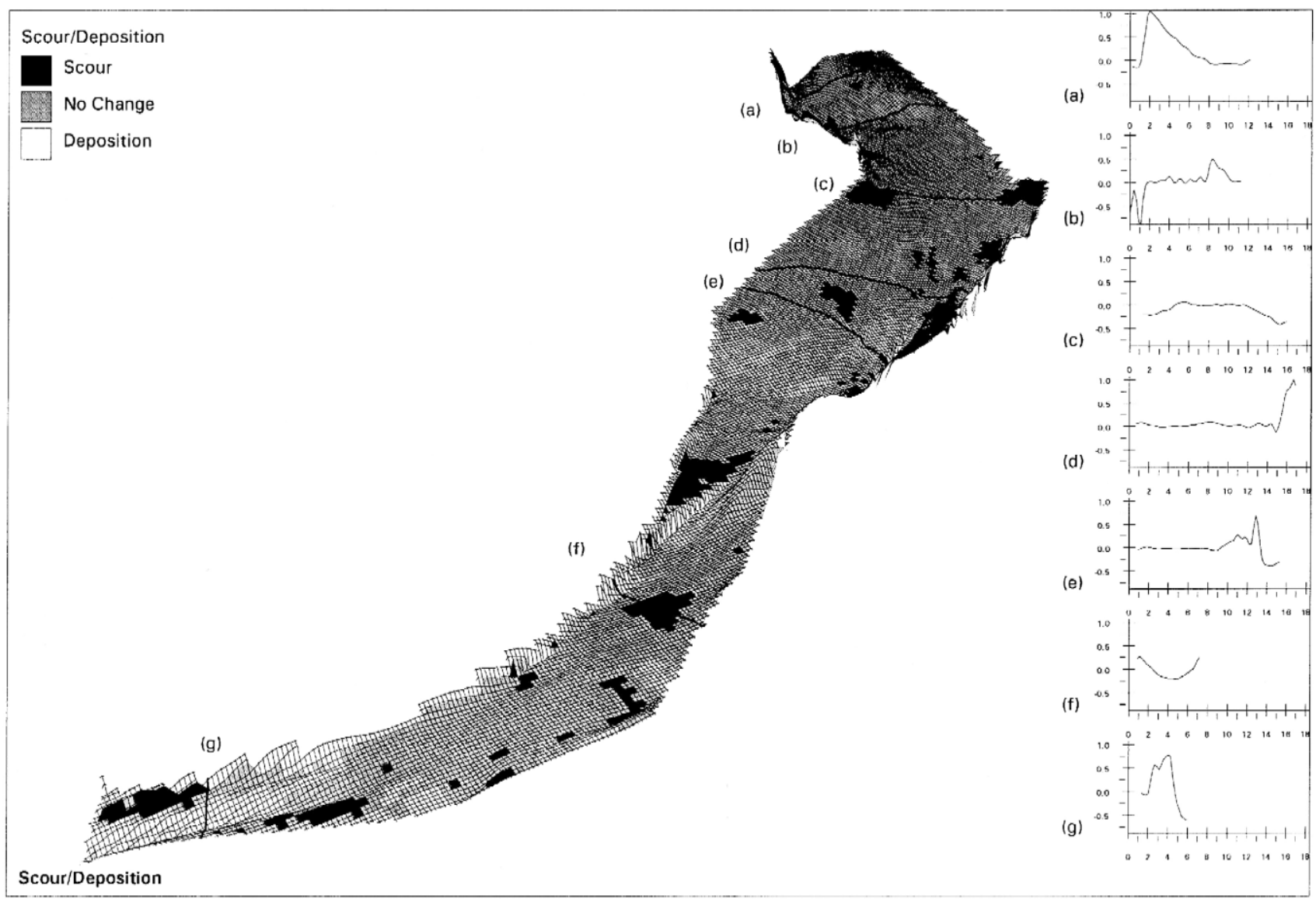

Fig. 8. Perspective plot indicating areas of scour and fill for the River Rede study site, between 1996 and 1997, as determined by cross-sectional re-surveys. The plot alongside indicate bed elevation change in metres at each of the sections labeled a-g. 
R2. The measure of entrainment potential suggests that the tail of R2 and P3 are unable to transport sediment, and hence, the material derived from P2 and the head of R2 is likely to be deposited there. A large region of potential entrainment is also apparent extending from the tail of R3 downstream through P4. At low flow $\left(0.07 \mathrm{~m}^{3} \mathrm{~s}^{-1}\right)$ no sediment entrainment (of the $D_{50}$ ) is predicted anywhere in the study reach.

\subsection{Observed morphological changes}

Morphological changes, based on changes in bed surface elevation between May 1996 and May 1997, are illustrated in Fig. 8. The magnitude of scour and fill is also indicated for seven cross-sections taken at selected intervals throughout the reach. The differences represent net change over this 12-month period, and hence, cannot represent zones of scour and fill associated with individual flood events. It is, however, possible to infer the direction of change, and to an extent, relate process to form. This may be achieved by comparing predicted areas of entrainment to the observed areas of activity. Most of the reach appears relatively stable although local zones of scour and fill are evident, which tend to be concentrated in the areas that are predicted in Fig. 7. One of the main zones of morphological change is found along the right bank of P1 extending to the tail of that particular pool. Scour of the channel banks has resulted in addition of sediment to the pool bed and a localised increase in bed elevation of approximately $1 \mathrm{~m}$ (Fig. 8a). Scour of the bed of P1 slightly further downstream is also evident on the right bank, which is matched by accretion of bar 1 (Fig. 8b). Bank collapse is also a feature shown at the tail of R1 (Fig. 8d). Further downstream, the entrainment appears to have been over-predicted in the centre of R1 after a flow of $8.52 \mathrm{~m}^{3} \mathrm{~s}^{-1}$, whereas the right-hand bank of R2 and R3 at discharges of 5.44 and $7.26 \mathrm{~m}^{3} \mathrm{~s}^{-1}$, respectively, are consistent with the observed areas of scour in Fig. 7. Scour predicted for P2 at 5.44 $\mathrm{m}^{3} \mathrm{~s}^{-1}$ also appears to be validated by cross-sectional re-survey with approximately $0.25 \mathrm{~m}$ along the left bank, accompanied by accretion of approximately $0.5 \mathrm{~m}$ along the margin of bar 2 .

\section{Discussion}

The results of this study confirm that, with increasing discharge, the hydraulic behaviour of riffle-pool sequences is complex. The data indicate that as discharge progressively increases, the velocity in pools increases at a faster rate in comparison to the riffles. Of the six riffle-pool units analysed, four demonstrated a marginal velocity reversal at high flow, thus supporting the reversal hypothesis of Keller (1971). The study reach on the Rede should favour the phenomenon of tractive force reversal for two reasons. Firstly, its pool sediments are coarser than those on the riffles, increasing the grain roughness of the pools. Secondly, pool channel widths are much narrower than those of riffles (Table 2). Carling and Wood (1994) have demonstrated using computer simulation the increased potential for velocity reversal where the pools have a higher grain roughness and where riffles are in excess of 50\% wider than the pools. However, the data presented in Fig. 5 could alternatively be interpreted as demonstrating 
equalisation given uncertainty in the measurement errors, secondary flows, and the confidence limits on the data scatter. Although boundary shear stress data further support the occurrence of a tractive force reversal, their interpretation should also be approached with some caution as three dimensional flow effects and turbulence are not accounted for by the Du Boys equation.

Observations suggest that the position of velocity and boundary shear stress maxima within the study reach change with stage. Furthermore, it was clear that maximum tractive force did not always occur at bankfull discharge for some riffle-pool units. This is due to the balance of the input data to Eq. (6); although water depth is greater at bankfull (having the effect of increasing $\tau_{0}$ ), water surface slope tends to flatten out (particularly over riffles), which has the opposite effect and may be sufficient to reduce $\tau_{0}$ values even though stage is higher. Boundary shear stress reversals require the product of water surface slope and depth in the pool to exceed that of the riffle. Slope data tend to indicate that pool slopes exceed those of riffle slopes at higher flows (Table 2 ), although it is still feasible for shear stress reversal to occur without the pool water surface slope exceeding that of adjacent riffles if the riffle slope decreases sufficiently and the pool depth is greater.

\subsection{Sediment sorting and transport}

Sediment sorting patterns on the Rede support the occurrence of tractive force reversal as pools were found to contain coarser sediments in comparison to those on the surface of the riffles, indicating higher competence within the pools with exceptions such as Thompson et al. (1999), this sorting pattern has not recently been widely reported. More frequently pools have been reported to contain finer-grained sediments than adjacent riffles (Keller, 1971; Lisle, 1979; Bhowmik and Demissie, 1982a; Milne, 1982; Hirsch and Abrahams, 1984; Clifford, 1993; Sear, 1996), possibly as a result of the coarser lag gravel being buried by fines winnowed from the upstream riffle.

Although some bed armour mobilisation was noted for the Rede, observations up to September 1998 suggest that most of the material, which is transported by flows below two-thirds bankfull is smaller than $32 \mathrm{~mm}$ in diameter (mainly phase 1 bedload). Observations from the Rede appear to be supported by the work of Carling (1988) on Great Eggleshope Beck and Carl Beck, UK, where phase 1 transport of fine bedload was found to dominate the bedload at flows up to $60 \%$ bankfull. Due to the structural stability exhibited by the riffle morphology on the Rede, it appears that the surface layer of sediment behaves like a static armour (sensu Chin et al., 1994), still allowing non-riffle material to be transported over its surface while not actually being mobilised fully itself. Patchy armour layer disruption (phase 2 transport) similar to that observed by Carling (1988) does appear to occur at flows approaching bankfull, however, no significant change in riffle morphology was found during the period of this investigation. It is feasible that flows of greater magnitude, possibly up to the $130 \%$ bankfull suggested by Carling (1988), are required to fully mobilise the bed surface on the Rede. It is unlikely that riffles provide significant quantities of sediments for transport. Instead, the principal source of sediment during moderate bedload transport events is probably 
derived from upstream point bars where sediments tend to be finer and less compacted than permanently wetted channel materials (Carling et al., 1998), whereas at discharges of bankfull and above, secondary sediment sources may originate from the re-working of channel banks, particularly along the margins of pools (Carling et al., 1998). These materials are then re-deposited on topographic highs further downstream.

\section{Conclusions}

The velocity data presented support the reversal hypothesis of Keller (1971) and illustrate the potential of using boundary shear stress to describe the spatial and temporal behaviour of flow hydraulics through riffle-pool units. Although the Du Boys Eq. (6) was designed for uniform flow conditions, its use could be justified in this instance as, with the exception of one flow condition $\left(2 \mathrm{~m}^{3} \mathrm{~s}^{-1}\right)$, non-uniform effects were negligible ( $\beta$ coefficient deviation \pm 0.1 ). Several points arise from these data obtained for the Rede. During floods, there is a tendency for peak tractive force to be located in pools and to exceed that over the riffles. Reversals in tractive force can occur at flows as little as one-third bankfull in the case of the River Rede, however, the highest values of boundary shear stresses throughout the whole reach were found at bankfull discharge. Riffle-pool units appear to operate independently of one another and show reversals at different stages on the flood hydrograph, with the zone of peak boundary shear stress and velocity appearing to move downstream through the reach as discharge progressively increases.

The spatial distribution and magnitude of morphological change in terms of sediment transport potential may be predicted by subtracting $\tau_{\mathrm{c}}$ from $\tau_{0}$. Actual scour and fill patterns, which had occurred over the period 1996-1997 correlated well to predictions in the upper half of the River Rede study reach. However, some areas of entrainment appear to be over-predicted, which may be due to differences in microtopographical bedform, which are known to vary between riffles and pools (Sear, 1992b,c); riffles tend to exhibit greater structural development in comparison to pools. The arrangement of particles influences scour and fill by altering $\theta_{c}$ for entrainment. Although structural effects are partly accounted for by using Andrews (1983) approach, a more precise estimate of $\theta_{c}$ should be obtained from sediment tracer data for the Rede site itself in order to improve prediction of scour, which is the focus of continuing research.

\section{Acknowledgements}

Financial support from the Department of Geography University of Newcastle upon Tyne is gratefully acknowledged. We would like to thank Ed Keller and Paul Carling for their constructive reviews. Colin Thorne deserves particular thanks for improving the clarity of an earlier version of the manuscript, whilst James Bathurst, Tom Lisle and Ian Fuller all made helpful comments. Ann Rooke kindly produced Fig. 2a. 


\section{References}

Andrews, E.D., 1979. Scour and fill in a stream channel: East Fork River, Western Wyoming. United States Geological Survey Professional Paper, 1117.

Andrews, E.D., 1983. Entrainment of gravel from naturally sorted riverbed material. Geol. Soc. Am. Bull. 94, 1225-1231.

Ashworth, P.J., 1987. Bedload transport and channel change in gravel-bed rivers. Unpublished PhD Thesis, University of Stirling, UK.

Bathurst, J.C., 1977. Resistance to flow in rivers with stony beds. PhD Thesis, University of East Anglia, UK.

Bathurst, J.C., 1982. Discussion. In: Hey, R.D., Bathurst, J.C., Thorne, C.R. (Eds.), Gravel-bed Rivers. Wiley, pp. 57-58.

Bhowmik, N.G., 1982a. Shear stress distribution and secondary currents in straight open channels. In: Hey, R.D., Bathurst, J.C., Thorne, C.R. (Eds.), Gravel-bed Rivers. Wiley, pp. 31-55.

Bhowmik, N.G., 1982b. Reply. In: Hey, R.D., Bathurst, J.C., Thorne, C.R. (Eds.), Gravel-bed Rivers. Wiley, pp. 59-60.

Bhowmik, N.G., Demissie, M., 1982a. Bed material sorting in pools and riffles. J. Hydraul. Eng., Am. Soc. Civ. Eng. 108, 1227-1231.

Bhowmik, N.G., Demissie, M., 1982b. Closure. J. Hydraul. Div., Am. Soc. Civ. Eng. 109, 1245-1247.

Bray, D.I., 1980. Evaluation of boundary roughness for gravel-bed rivers. Can. J. Civ. Eng. 7, 392-397.

Brookes, A., 1990. Restoration and enhancement of engineered British river channels: some European experiences. Reg. Rivers Res. Manage. 5, 45-56.

Brookes, A., 1992. Recovery and restoration of some engineered British river channels. In: Boon, P.J., Calow, P., Petts, G.E. (Eds.), River Conservation and Management. Wiley, Chichester, pp. 337-352.

Buffington, J.M., Montgomery, D.R., 1997. A systematic analysis of eight decades of incipient motion studies, with special reference to gravel-bedded rivers. Water Resour. Res. 33, 1993-2029.

Carling, P.A., 1988. Dominant discharge and channel stability thresholds. Earth Surf. Processes Landforms 13, 355-367.

Carling, P.A., 1991. An appraisal of the velocity-reversal hypothesis for stable pool-riffle sequences in the river Severn, England. Earth Surf. Processes Landforms 16, 19-31.

Carling, P.A., Wood, N., 1994. Simulation of flow over pool-riffle topography: a consideration of the velocity reversal hypothesis. Earth Surf. Processes Landforms 19, 319-332.

Carling, P.A., Williams, J.J., Kelsey, A., Glaister, M.S., Orr, H.G., 1998. Coarse bedload transport in a mountain river. Earth Surf. Processes Landforms 23, 141-157.

Cherkauer, D.S., 1973. Minimisation of power expenditure in a riffle-pool alluvial channel. Water Resour. Res. 9, 1613-1628.

Chin, C.O., Melville, B.W., Raudkivi, A.J., 1994. Streambed armouring. J. Hydraul. Eng., Am. Soc. Civ. Eng. 120, 899-918.

Clifford, N.J., 1993. Differential bed sedimentology and the maintenance of a riffle-pool sequence. Catena 20, $447-468$.

Clifford, N.J., Richards, K.S., 1992. The reversal hypothesis and the maintenance of riffle-pool sequences: a review and field appraisal. In: Carling, P.A., Petts, G.E. (Eds.), Lowland Floodplain Rivers: Geomorphological Perspectives. Wiley, pp. 43-70.

Dolling, R.K., 1968. Occurrence of pools and riffles: an element in the quasi-equilibrium state of river channels. Ont. Geogr. 2, 3-11.

Ferguson, R.I., 1993. Understanding braiding processes in gravel-bed rivers: progress and unsolved problems. In: Best, J.L., Bristow, C.S. (Eds.), Braided Rivers, Geological Society Special Publication vol. 75. The Geological Society, London, pp. 73-87.

Gilbert, G.K. 1914. Transportation of débris by running water. US Geological Survey Professional Paper, 294-B.

Greenwood, M.T., Richardot-Coulet, M., 1996. Aquatic invertebrates. In: Petts, G.E., Amoros, C. (Eds.), Fluvial Hydrosystems. Chapman \& Hall, London, pp. 137-166.

Hack, J.T., 1957. Studies in longitudinal stream profiles in Virginia and Maryland. USGS Professional paper, 294B. 
Heslop, S.E., Allen, C.M., 1989. Turbulence and dispersion in larger UK rivers. Proceedings of the International Association of Hydraulic Research Congress, Ottawa, Canada. pp. D75-D82.

Hirsch, P.J., Abrahams, A.D., 1984. The properties of bed sediments in pools and riffles. J. Sediment. Petrol. 51, 757-760.

Jackson, W.L, Beschta, R.L., 1982. A model of two-phase bedload transport in an Oregon Coast Range stream. Earth Surf. Processes Landforms 7, 517-527.

Keller, E.A., 1970. Bed-load movement experiments: Dry Creek, California. J. Sediment. Petrol. 40, 1339-1344.

Keller, E.A., 1971. Areal sorting of bed-load material: the hypothesis of velocity reversal. Geol. Soc. Am. Bull. 82, 753-756.

Keller, E.A., 1972. Areal sorting of bed-load material: the hypothesis of velocity reversal. A reply. Geol. Soc. Am. Bull. 83, 915-918.

Keller, E.A., 1982. Bed material sorting in pools and riffles. J. Hydraul. Div., Am. Soc. Civ. Eng. 109, 1243-1245.

Keller, E.A., Florsheim, J.L., 1993. Velocity-reversal hypothesis: a model approach. Earth Surf. Processes. Landforms 18, 733-740.

Keller, E.A., Melhorn, W.N., 1978. Rhythmic spacing and origin of pools and riffles. Geol. Soc. Am. Bull. 89, 723-730.

Leopold, L.B., Wolman, M.G., Miller, J.P., 1964. Fluvial processes in geomorphology. Freeman, San Francisco, CA.

Lisle, T.E., 1979. A sorting mechanism for a riffle-pool sequence: summary. Geol. Soc. Am. Bull. 90, 616-617.

Lisle, T.E., Hilton, S., 1992. The volume of fine sediment in pools: an index of sediment supply in gravel-bed streams. Water Resour. Bull. 28, 371-383.

Lisle, T.E., Hilton, S., 1999. Fine bed material in pools of natural gravel bed channels. Water Resour. Res. 35, 1291-1304.

Milan, D.J., Petts, G.E., Sambrook, H., in press. Regional variations in sediment structure of trout streams in southern England: benchmark data for situation assessment and restoration. Aquatic Conservation Marine and Freshwater Ecosystems.

Milan, D.J., Heritage, G.L., Large, A.R.G., Brunsden, C.F., 1999. Influence of particle shape and sorting upon sample size estimates for a coarse-grained upland stream. Sediment. Geol. 128, 85-100.

Miller, M.C., McCave, I.N., Komar, P.D., 1977. Threshold of sediment motion under unidirectional currents. Sedimentology 24, 507-527.

Milne, J.A., 1982. Bed-material size and the riffle-pool sequence. Sedimentology 29, 267-278.

Newbury, R., 1995. Rivers and the art of stream restoration, Natural and Anthropogenic influences in Fluvial Geomorphology. Geophysical Monograph vol. 89. American Geophysical Union.

O’Connor, J.E., Webb, R.H., Baker, V.R., 1986. Paleohydrology of pool-riffle pattern development: Boulder Creek, Utah. Geol. Soc. Am. Bull. 97, 410-420.

Petit, F., 1987. The relationship between shear stress and the shaping of the bed of a pebble-loaded river, La Rulles-Ardenne. Catena 14, 453-468.

Richards, K.S., 1976a. Channel width and the riffle-pool sequence. Geol. Soc. Am. Bull. 87, 883-890.

Richards, K.S., 1976b. The morphology of riffle-pool sequences. Earth Surf. Processes Landforms 1, 71-88.

Richards, K.S., 1978. Simulation of flow geometry in a riffle-pool stream. Earth Surf. Processes Landforms 3, 345-354.

Robert, A., 1997. Characteristics of velocity profiles along riffle-pool sequences and estimates of bed shear stress. Geomorphology 19, 89-98.

Sear, D.A., 1992a. Sediment transport processes in riffle-pool sequences in a river experiencing hydropower regulation. In: Hey, R.D., Billi, P., Thorne, C.R., Tacconi, P. (Eds.), Dynamics of Gravel-bed Rivers. Wiley, Chichester, pp. 629-650.

Sear, D.A., 1992b. Sediment transport processes in riffle-pool sequences and the effects of river regulation for hydroelectric power in the River North Tyne. Unpublished PhD Thesis, University of Newcastle-upon-Tyne, UK.

Sear, D.A., 1992c. In: Hey, R.D., Billi, P., Thorne, C.R., Tacconi, P. (Eds.), Dynamics of Gravel-bed Rivers. Wiley, Chichester, p. 292, Discussion. 
Sear, D.A., 1996. Sediment transport processes in pool-riffle sequences. Earth Surf. Processes Landforms 21, 241-262.

Strahler, A.N., 1952. Hyposometric (area-altitude) analysis of erosional topography. Bull. Geol. Soc. Am. 63, 1117-11142.

Teissyre, A.K., 1984. The River Bóbr in the Blazkowa study reach (central Sudetes): a case study in fluvial processes and fluvial sedimentology. Geol. Sudetica 19, 7-71.

Teleki, P.G., 1972. Areal sorting of bed-load material: the hypothesis of velocity reversal: discussion. Geol. Soc. Am. Bull. 83, 911-914.

Thompson, D.M., Wohl, E.E., Jarrett, R.D., 1999. Velocity reversals and sediment sorting in pools and riffles controlled by channel constrictions. Geomorphology 27, 229-241.

Whiting, P.J., Dietrich, W.E., 1991. Convective accelerations and boundary shear stress over a channel bar. Water Resour. Res. 27, 783-796.

Wolman, M.G., 1954. A method of sampling coarse river gravels. Trans., Am. Geophys. Union 35, 951-956.

Yang, T.C., 1971. Formation of riffles and pools. Water Resour. Res. 17, 1557-1574. 